\title{
The Most Insignificant Justice: A Preliminary Inquiry
}

David P. Currie †

I was intrigued in the course of recent research into early constitutional decisions by Irving Dilliard's indignant rejection of the assertion that Gabriel Duvall was " "probably the most insignificant of all Supreme Court Judges." "1 Since Mr. Dilliard does not suggest which Justice or Justices were more insignificant than Duvall, I have made a preliminary investigation of my own.

I acknowledge at the outset the highly subjective nature of the inquiry. Insignificance, as every Chicago Cub supporter knows, is in the eye of the beholder. Yet every baseball town has its particular favorites: the shortstop who regularly threw the ball into the lower grandstand; the pitcher who habitually walked batters when the bases were loaded; the slugger who struck out whenever he came up with men on base. ${ }^{2}$ In hopes of identifying individuals of comparable stature in the judicial field, I have devised a set of $\mathrm{Ob}$ jective Indicators of Insignificance ("OII"), which, I am modestly confident, will provide the most skeptical reader with substantial scientific support for my more informal assessments of candidates for the coveted laurels of Most Insignificant Justice.

It seems only appropriate to begin with Duvall himself, not only because Dilliard's unsubstantiated attack on his record provoked the present inquiry, but more importantly, because impartial examination of Duvall's performance reveals to even the uninitiated observer that he achieved an enviable standard of insignificance against which all other Justices must be measured.

Before attempting to make the case for Duvall, however, I

† Harry N. Wyatt Professor of Law, University of Chicago. I should like to thank none of my colleagues for help in composing this seminal article. None of them appeared to take it seriously.

1 Dilliard, Gabriel Duvall, in 1 The Justices of the UnIted States Supreme Court 1789-1969, at 419, 428 (H. Friedman \& F. Israel eds. 1969) (quoting E. BATEs, ThE STORY or THE SUPREME Court 109 (1936)).

2 Cf. Flood v. Kuhn, 407 U.S. 258, 262-63 (1972), where Justice Blackmun listed over 80 baseball players "celebrated for one reason or another," and where two Justices, id. at 285, dissented from the list. See also Aside, The Common Law Origins of the Infield Fly Rule, 123 U. PA. L. REv. 1474 passim (1975). 
should like to set to one side a number of contenders who attained a high level of invisibility simply because they had the unfair advantage of never getting off the ground. In this category we find such luminaries as Thomas Johnson of Maryland (1791-93), ${ }^{3}$ who drew his salary during a period when the Court had no cases to decide and who resigned after two years "rather than undertake the labor," and Robert Trimble of Kentucky (1826-28), who contrived to perish in his third year on the Bench, and who in contributing a respectable opinion in Ogden $v$. Saunders ${ }^{\bullet}$ had already disqualified himself by doing more than a number of his brethren whose years of service quintupled his own. Entitled to honorable mention as the only known Justice who missed two opportunities to become truly insignificant is the South Carolinian John Rutledge (1789-91 and 1795)," who when first appointed "[r]esigned without ever sitting,"8 and who upon being named Chief Justice several years later sat only on circuit before managing to persuade the Senate that his increasing mental instability was a sufficient ground for refusing to confirm him. ${ }^{2}$ To be insignificant for one or two years, however, is child's play; to maintain a profile of insignificance over a period of a decade or more is an accomplishment of high order.

Reasons of delicacy, it should be added, preclude consideration of any Justice who sat within the past thirty years, lest the subconscious desire to curry favor exaggerate or be thought to have exaggerated an assessment of the insignificance of some recent incumbent or of his friends. ${ }^{10}$ Finally, my evaluations are based solely upon decisions on matters of constitutional law, since those are the only ones I have read; my conclusions must be taken with the reservation that some Justice who preserved an impeccably bland profile in constitutional cases may have spoiled it by expos-

3 G. Gunther, Cases and Materials on Constitutional law app. A, at A-1 (10th ed. 1980).

- 1 C. Warren, The Supreme Court in United States History 85-86 (2d ed. 1926). Actually, what Johnson was griping about was circuit riding, which did demand the expenditure of time. Fairness in reporting, however, is a luxury.

- G. GunThER, supra note 3, at A-2.

- 25 U.S. (12 Wheat.) 213, 313-31 (1827).

7. Gunther, supra note 3, at A-1.

- Id.

- 1 C. WARREN, supra note 4, at 136-37.

30 It should also be added that the increased use of law clerks makes it ever more unlikely that future Justices will match the insignificance attained by some of their predecessors; it surely cannot be an easy task to achieve true insignificance with three or four of the country's brightest young lawyers buzzing about one's chambers. 
ing himself shamelessly in some other field of law.

With these introductory observations I turn to my first candidate for Most Insignificant Justice ("MIJ"), Gabriel Duvall. It speaks well for his candidacy that there is a threshold uncertainty as to the proper spelling of his name; it seems unlikely that anyone of much significance as recently as the nineteenth century could have made such a claim. In the teeth of annual fiyleaf notations by Reporters Cranch, Wheaton, and Peters uniformly employing the form "Duvall,"11 Marshall's biographer, Albert Beveridge, stubbornly insisted, without citation of authority, on spelling the name with a single "l."12 Mr. Dilliard, however, who for some unaccountable reason actually traced the family history, concluded persuasively that the original "DuVal" or "Duval" employed in earlier generations had become "Duvall" before the future Justice was born. ${ }^{13}$ I therefore am inclined to dismiss Mr. Beveridge's contrary view as the effort of a partisan observer unable to resist making his favorite appear more forgotten than he actually was.

Whether Duvall's name could be spelled either by his contemporaries or by later historians, in any event, is at best an indirect indicator of true insignificance, ${ }^{14}$ which is best assessed directly by an examination of his record. Appointed in 1811, Duvall endured until $1835 .^{15}$ In constitutional cases he was recorded as having delivered one opinion in twenty-five years, and it can be quoted in full: "Duvall, Justice, dissented." The occasion was the Dartmouth College case, ${ }^{17}$ in which three of his colleagues had written opinions totaling ninety pages to explain that the state had impaired the college's charter; Duvall managed to dispute them all in just three words.

On even the uninitiated eye, I submit, this brief but exhaus-

11 See volumes 11-33 of the United States Reports.

124 A. Beveridge, The Life of John Marshall 60 n.1 (1919).

1s See Dilliard, supra note 1 , at $420-21$.

16 In the same category is Dilliard's revelation that Duvall "was the only one eligible who was omitted from the original twenty volumes of the Dictionary of American Biography." Id. at 428 .

${ }^{16}$ See G. Gunther, supra note 3, at A-2. The traditional term "served" has been deliberately avoided in this study because it appears to imply some contribution to the work of the Court and therefore to prejudice an impartial inquiry.

18 Trustees of Dartmouth College v. Woodward, 17 U.S. (4 Wheat.) 518, 713 (1819) (Duvall, J., dissenting) (4th ed. 1902). It is tempting to interpret Wheaton's capitalization as an editorial comment on the epochal breaking of Duvall's eight-year silence, but a few pages earlier one finds similarly archaic references to "MARSHALL" and "STORY," neither of whom remotely approached Duvall's record of taciturnity. See 17 U.S. (4 Wheat.) at 624, 666 (4th ed. 1902).

17 Trustees of Dartmouth College v. Woodward, 17 U.S. (4 Wheat.) 518 (1819). 
tive restatement of Duvall's record must make a striking impression. To encumber the highest bench for a quarter of a century without leaving any deeper imprint than Duvall did is the mark of a very special judge. Application of the objective indicator of insignificance PPY (Pages Per Year), however, will quickly confirm in more scientific terms the true extent of Duvall's accomplishment. Duvall sat for twenty-five years and wrote three words. Three words in the type face employed by Wheaton in 1819 occupied a little less than half a line; $;^{18}$ on the page preceding Duvall's dissent there were twenty-two lines. ${ }^{19}$ Thus Duvall's output $(P)$ totaled 0.02 pages $^{20}$ and his years $(\mathrm{Y}) 25$; his PPY $(\mathrm{P} \div \mathrm{Y})$ is therefore $0.02 \div 25$, or $0.0008 .{ }^{21}$ For the reader who is not mathematically inclined, this amounts to eight ten-thousandths of a page per year over a sustained period-an enviable record of insignificance that I think all will agree can be taken as a standard of comparison.

Ignoring the misleading perfect PPY scores of such fleeting figures as Thomas Johnson and John Rutledge for reasons already given, ${ }^{22}$ we find that Duvall had several serious rivals in terms of the critical PPY among his own brethren. For much of the time during which Duvall sat, thanks to John Marshall's insistence on writing everything himself, the Supreme Court was popularly known as "John Marshall and the Six Dwarfs."23 Of Marshall's colleagues only Joseph Story and William Johnson managed to say very much of interest-the latter by having the temerity to disagree on rare occasions with the party line ${ }^{24}$ and the former essentially by waiting until Marshall was either disqualified ${ }^{25}$ or dead. ${ }^{28}$

1s See 17 U.S. (4 Wheat.) at 713 (4th ed. 1883). Ideally one should correct for variability of type size from volume to volume; I shall do so, however, only upon a showing that some other Justice enjoyed such a facially astounding PPY as that of Duvall.

10 Id. at 712.

${ }^{20}$ I have taken the liberty of rounding off to the nearest hundredth of a page. For those chained to precision, Duvall's output is a repeating decimal: 0.0227 .

21

$$
\begin{array}{r}
0.0008 \\
2 5 \longdiv { 0 . 0 2 0 0 } \\
200 \\
\hline
\end{array}
$$

22 See supra notes $3,4,7,9$ and accompanying text.

23 I say "was" in the confident expectation that future scholars will adopt this handy characterization after reading this article. Feel free to use it, preferably with the appropriate attribution, i.e., Currie, The Most Insignificant Justice: A Preliminary Inquiry, 50 U. CuI. L. Rev. 466, 469 (1983).

24 See D. Morgan, Justice Whliam Johnson: The First Dissentrer passim (1954).

${ }^{25}$ See Martin v. Hunter's Lessee, 14 U.S. (1 Wheat.) 304, 323-62 (1816).

26 Marshall died in 1835; Story determinedly sat for another 10 years. See G. GuNTHRR, 
Bushrod Washington, in contrast, who was on the Court even longer than was Duvall, ${ }^{27}$ managed to remain completely inactive in constitutional cases from 1798 until 1820, a period of uninterrupted quiescence very likely unequalled in the history of the Court-only to blow it all by writing a full handful of extensive and unfortunately well-crafted opinions once old age had evidently weakened his resolution. ${ }^{28}$ Brockholst Livingston, who maintained a tomblike silence throughout his seventeen years in Washington, ${ }^{29}$ demonstrates the danger of relying on Supreme Court PPY alone as a measure of overall insignificance: his circuit-court opinions reveal him to have been in fact a closet overachiever who in at least one instance sat slyly by while Marshall delivered for the whole Court an opinion inferior to that which Livingston had already prepared in the boondocks. ${ }^{30}$ Harder to dismiss is Thomas Todd of Kentucky, whose unblemished muteness outdid even that of Livingston by two long years, ${ }^{31}$ who therefore has probably the longest sustained zero PPY of any Justice, and who is not known to have disqualified himself by writing anything of significance on circuit. ${ }^{32}$ Once again, however, it is well to bear in mind that PPY, though scientifically derived, is not an end in itself but merely one tool for assessing overall insignificance. I appeal to the reader's sense of fair play in asking whether a single lapse of three words in a twenty-five-year career should be permitted to outweigh the fact that Duvall had twenty-four years of total anonymity, and Todd had only nineteen. ${ }^{3 s}$

supra note 3, at A-2.

27 Washington was on the Court from 1798 until 1829. See G. GuNTHER, supra note 3, at A-2. For Duvall's duration on the Court, see supra note 15 and accompanying text.

${ }^{28}$ E.g., Houston v. Moore, 18 U.S. (5 Wheat.) I (1820). See Currie, The Constitution in the Supreme Court: The Powers of the Federal Courts, 1801-1835, 49 U. CHI. L. REv. 646, 702-05 (1982).

20 Livingston was on the Court from 1806 until 1823. See G. GunTHRR, supra note 3, at A-2. For a discussion of his activity there (or lack thereof), see Currie, supra note 28, passim; Currie, The Constitution in the Supreme Court: State and Congressional Powers, 1801-1835, 49 U. CHI. L. Rev. 887 passim (1982).

so See Currie, supra note 29, at 915 (discussing Adams v. Storey, 1 F. Cas. 141, 143-44 (C.C.D.N.Y. 1817) (No. 66)).

s1 Todd was on the Court from 1807 until 1826. G. GunTHER, supra note 3, at A-2.

${ }^{38}$ Actually I haven't looked. Thus the statement in the text is accurate: Todd is "not known" (by me) "to have written anything of significance on circuit." I take further comfort from the conclusion of a leading study of the period that Todd's overall contributions were "minimal." G. Haskins \& H. Johnson, History of the Supreme Court of the United STATES 391 (1981).

ss If all else fails I should be forced to insist that we are not certain that Duvall actually uttered the three words ("Duvall, Justice, dissented") that he is accused of having uttered in the Dartmouth College case, see supra notes 16-17 and accompanying text. Indeed the 
Duvall's detractors seldom fail to emphasize that he, like John Rutledge, ${ }^{34}$ had an unfair advantage: it was easy for him not to deliver opinions since, as Dilliard puts it, in his later years he was " 'so deaf as to be unable to participate in conversation." "ss The analogy to Rutledge, however, seems strained. Rutledge had the easy excuse for inaction that during most of his potentially productive years he was not a member of the Court and therefore was not legally entitled to deliver its opinions. There is no proof, in contrast, that Duvall was either dead or unable to speak while on the Court, and it is by no means uncommon for judges to deliver lengthy opinions on matters they do not begin to understand. On the quantitative scale of PPY, therefore, modified by common sense and a spirit of fair play, Duvall seems to me far and away the most insignificant of his colleagues during the time of Chief Justice Marshall.

As we move to the more egalitarian times of later Chief Justices, ${ }^{38}$ when mere Associate Justices were increasingly allowed to open their mouths, we have great difficulty finding rivals to the original Dwarfs in terms of PPY. In a sense the achievements of all of Marshall's colleagues should be to some extent discounted: no later Justice had the same advantage of serving under a Chief Justice who deprived him of pencils. ${ }^{37}$ In this light it seems to me that in terms of PPY weighted according to opportunity Duvall en-

peculiar phraseology employed strongly suggests he did not; unusual as it was for Duvall to speak at all, it would have been still more unusual for him to speak of himself in the third person and in the past tense. It seems more probable that the Reporter was paraphrasing an actual opinion of only two words (e.g., "I [i.e., Justice Duvall] dissent."). This fact alone, if it is a fact (my hypothesis is corroborated by the fact that different reports of the case contain varying versions of the opinion, see, e.g., 17 U.S. (4 Wheat.) 518, 713 (1st ed. New York 1819) (Duvall, J., dissenting) ("Mr. Justice Duvall dissented") (emphasis added)), would have the effect of reducing Duvall's already impressive PPY by fully one third (actually, more than a third; PPY is based on space, not number of words, and "I" is far smaller than "Duvall, Justice"). Indeed, for all we know, Wheaton may simply have misinterpreted a sneeze by Duvall after the Chief Justice asked whether anybody disagreed with the majority's decision. Whether Duvall actually sneezed, I hasten to add, is a matter of conjecture. I do not rely on it for my conclusion.

st See supra notes 7-9 and accompanying text.

as Dilliard, supra note 1 , at 427 (quoting the admittedly "young" and inexperienced Charles Sumner).

so Analogy might suggest (cf. attorneys-general, mothers-in-law) that the correct plural form is Chiefs Justice. The resolution of this issue, fortunately, is beyond the scope of the present study.

s7 This feat demonstrates once again the enormous ingenuity of the great Chief Justice, for it is by no means clear that the pencil had yet been invented. Cf. U.S. CoNST. art. I, $\S 8$, cl. 8: "To promote the Progress of Science and useful Arts, by securing . . . to . . . Inventors the exclusive Right to their ... Discoveries . . . ." 
counters a most serious rival in Justice John McKinley of Kentucky, who was nominally a member of the Court for fifteen long years after Marshall's departure (1837-52) ${ }^{38}$ and who left practically no trace.

I think it can be said without fear of contradiction that the name John McKinley is not a household word. He authored in those quiescent years not one opinion for the Court in a constitutional case; as Professor Swisher has succinctly observed, McKinley "seldom wrote opinions of any kind." alone as having missed four entire Terms of the Supreme Court ${ }^{40}$ while he was a member of that body, ${ }^{41}$ once giving as his justification that he had pressing business on circuit. ${ }^{42}$ Upon McKinley's death Chief Justice Taney paid him the tellingly lukewarm compliment of having been "faithful and assiduous" when he managed to attend, 43 and Professor Swisher was able in his monumental study of the period to conclude without qualification that in his entire career McKinley "made no significant contribution to legal thinking in any form."

Nevertheless, despite his obvious achievements, even McKinley was no real rival to Duvall in strict PPY terms, for in fifteen years he did produce two uninspired separate opinions amounting to twelve pages. ${ }^{45}$ His PPY of $0.8000,{ }^{46}$ although very likely the

s8 See G. GuNTHER, supra note 3, at A-3.

s9 C. Swisher, 5 History of the Supreme Court of the Umied States 120 (1974).

to See 39 U.S. (14 Pet.) at vii (3d ed. 1899); 42 U.S. (1 How.) following title page (2d ed. 1883); 47 U.S. (6 How.) following title page (2d ed. 1884); 49 U.S. (8 How.) at iii (2d ed. 1884). See also C. Swisher, supra note 39, at 463 ("Justice McKinley's attendance was never more than sporadic.").

"1 Others, of course, missed even more Terms either before their appointment or after their resignation, or both.

${ }^{42}$ See 49 U.S. (8 How.) at iii (2d ed. 1884). If this is true, of course, it detracts from the significance of his absence. Cf. supra notes $29-30$ and accompanying text (discussing Livingston, J.). The abolition of circuit riding in 1911 gave to later Justices an immeasurable advantage comparable to the impact on batting averages of the introduction of the live ball.

is 55 U.S. (14 How.) at v. Taney's actual words were "while his health was sufficient to undergo the labor."

4 C. Swisher, supra note 39 , at 67.

45 See (only) Bank of Augusta v. Earle, 38 U.S. (13 Pet.) 519, 597-606 (1839) (McKinley, J., dissenting); Passenger Cases, 48 U.S. (7 How.) 283, 452-55 (1849) (McKinley, J., concurring). Neither opinion addressed the constitutional provisions that were in issue.

46 $\mathrm{P}=(606-597)+(455-452)=9+3=12$. See supra note $45 . \mathrm{Y}=1852-1837=$ 15. See supra note 38 and accompanying text. $P P Y=P \div Y=12 \div 15=0.8000$ :

$$
\begin{gathered}
\frac{0.8000}{12.0000} \\
\frac{120}{0000}
\end{gathered}
$$


lowest of any Justice of long tenure who was equipped with a pencil, remains a thousand times that of Duvall. ${ }^{47}$ If later comers were to have a sporting chance to be recognized as $\mathrm{MIJ}$, therefore, it was necessary to devise additional OII to take into account the fact that insignificance can be manifested in a variety of ways. For it is widely accepted among scholars-though to my knowledge it has never been scientifically demonstrated-that not all pages of words are of equal intellectual value. Thus I have developed the additional parameter IPP (Inanities Per Page) in an effort to evaluate the qualitative as well as the quantitative component of insignificance.

In terms of IPP, it should be noted, Justice Duvall does not fare nearly so well. His one opinion, it will be remembered, ${ }^{48}$ read in its entirety "DuvalL, Justice, dissented." Favorable though I am to Duvall's cause, candor requires the concession that there is nothing particularly inane about this opinion. Although a critic with nothing better to do with his time than to read long opinions might perhaps have quibbled for a somewhat fuller statement of reasons, I submit that it is difficult to point to a single misstatement or even ambiguity in the entire pronouncement-a statement I would not have the audacity to make of any of the three other opinions in the case. Indeed the persistent Mr. Dilliard has gone to the length of arguing that Duvall's unusual brevity in the Dartmouth College case was evidence of extraordinary pugnacity and independence of mind: by saying so little the Justice "showed what he thought of Webster's long oratorical plea before the bench and of Chief Justice Marshall's pioneering decision for the Supreme Court"49-i.e., not much. In my opinion Dilliard has once more gone too far; his wholly unsupported conjecture may, I believe, be disregarded as the wishful thinking of a less than impartial observer. But the fact remains that Duvall does not rank high on the scale of inanities per page.

To illustrate the importance of IPP as an independent index of insignificance, I should like to discuss briefly the case of Justice Nathan Clifford, who occupied the bench for over twenty years between 1858 and $1881 .^{\circ 0}$ On the PPY scale Clifford was no threat to Duvall, for he wrote incessantly. However, he also wrote with less persuasive effect, so far as my limited researches have yet revealed,

67 See supra note 21 and accompanying text.

6s See supra notes 16-17 and accompanying text. But cf. supra note 33 .

18 Dilliard, supra note 1 , at $\dot{4} 20$.

so See G. Gunther, supra note 3, at A-3. 
than anyone else who ever sat on the supreme bench.

This is extravagant praise indeed, and the reader is entitled to supporting evidence. At the outset let me observe-without attempting to evade my responsibility - that IPP is a great deal more difficult to measure than PPY. In the first place, to determine the former it is necessary actually to read the opinions, which (especially in the case of a Justice who ranks high on the IPP scale) can be a considerable burden. In addition, inanity is a more subjective concept than the number of words emitted; perhaps in a thorough study one should attempt to quantify it in terms of certain key words (e.g., "whereas," "party of the second part," "fairness," etc.) that all competent observers would agree are sure-fire indicators of an inferior mind. Until such more objective indicators are developed, however, I shall make the case for Clifford on a more subjective basis. ${ }^{.1}$

One prime example of Clifford's craft was his entirely superfluous forty-seven-page dissenting opinion in the Legal Tender Cases $^{52}$ in 1871 . There, the reader will recall, the Court by a fiveto-four margin overruled a precedent from the preceding Term ${ }^{\text {s3 }}$ and upheld Congress's authority to make paper money legal tender for public and private debts. Chief Justice Chase, who had written the earlier opinion, repeated his exhaustive arguments that the tender provision was not necessary to the exercise of any congressional power, that it offended the spirit of the Constitution, and that it deprived creditors of their property without due process of law. ${ }^{\text {s4 }}$ Justice Field added a long dissent of his own, ${ }^{\text {ss }}$ and Clifford sprang manfully into the nonexistent breach.

"Money, in the constitutional sense," he began, "means coins of gold and silver fabricated and stamped by authority of law as a measure of value, pursuant to the power vested in Congress by the Constitution." Standing alone, this passage may not appear particularly inane; its true value begins to emerge only when one considers that the word "Money" nowhere appears in the relevant

"1. Cf. Justice Stewart's famous statement with respect to "hard-core pornography" in Jacobellis v. Ohio, 378 U.S. 184, 197 (1964) (Stewart, J., concurring): "I shall not today attempt further to define the kinds of material I understand to be embraced within that shorthand description; . . . [b]ut I know it when I see it . . . ." (emphasis added).

${ }^{32} 79$ U.S. (12 Wall.) 457, 587-634 (1871). But cf. Dam, The Legal Tender Cases, 1981 Sup. CT. REv. 367, 390 ("Justice Clifford doubtless came closer to the mark" than did Chief Justice Chase).

ss Hepburn v. Griswold, 75 U.S. (8 Wall.) 603 (1870).

st 79 U.S. (12 Wall.) at $570-87$ (Chase, C.J., dissenting).

ss Id. at 634-81 (Field, J., dissenting).

se Id. at 587 (Clifford, J., dissenting) (footnote omitted). 
provisions of the Constitution. ${ }^{57}$ Clifford might as pertinently have begun by stating that "dogs, in the constitutional sense, are dangerous mammalian quadrupeds that sully my lawn."158

Deftly turning still further from the issue before him, Clifford began with obvious relish to describe in considerable detail the terms of the statute establishing the mint in 1792. I quote in full his remarkably trenchant description of the coins initially authorized to be minted:

First, gold coins, to wit: Eagles of the value of ten dollars or units; half-eagles of the value of five dollars; quarter-eagles of the value of two and a half dollars, the act specifying in each case the number of grains and fractions of a grain the coin shall contain, whether fabricated from pure or standard gold. Second, silver coins, to wit: "DOLLARS OR UNITS," each to contain 371 grains and 4/16ths part of a grain of pure silver, or 416 grains of standard silver. Like provision is also made for the coinage of half-dollars, quarter-dollars, dimes, and half-dimes, and also for coinage of certain copper coins, but it is not necessary to enter much into those details in this case. ${ }^{59}$

No, it was not necessary; indeed one would have thought the entire tedious recitation added nothing whatever on the question of whether Congress might make something other than gold or silver legal tender..$^{80}$

Beginning on the very next page of the same opinion, moreover, we find the following remarkable sentence:

Completed, as the circle of measures adopted by Congress were, to put the new government into successful operation, by the passage of that act, it will be instructive to take a brief review of the important events which occurred within the period of ten years next preceding its passage, or of the ten years next following the time when that measure was first pro-

s7 It does appear in the borrowing clause, U.S. CoNST. art. I, § 8, cl. 2, but nobody disputed that what the Government was arguably borrowing when it issued tender notes was "Money." There is also, of course, a clause authorizing Congress "To coin Money," U.S. CoNST. art. I, $\S 8$, cl. 5 , but the majority did not rely on it, and it was certainly easier to point out that paper money was not "coin[ed]" than to argue that it was not money at all.

ss. infra note 70.

62 79 U.S. (12 Wall.) at 593 (Clifford, J., dissenting).

${ }^{\circ}{ }^{\prime}$ Note also the crafty use (on two distinct but parallel occasions) of the useless and stilted term "to wit." Cf. the discussion of the "sure-fire indicators of an inferior mind," supra text preceding note 51. 
posed in the Congress of the Confederation. ${ }^{\text {a1 }}$

Quite apart from the important substantive fact that Clifford was here continuing his journey into a blind alley, and apart from the interesting question whether he was planning to move forward or backward in time, we encounter in this single sentence abundant evidence of the surpassing inanity of Justice Clifford's style. Most striking is the blatant use of a plural verb with a singular subject ("the circle . . . were"), which is almost too obvious a mistake to be taken at face value. More subtle, in contrast, is the exquisitely dangling participle, half concealed by the intervention of three essentially incomprehensible clauses between subject and modifier: "Completed, . . . it will be instructive . . . ." One is reminded of the classic textbook example: "Foaming at the mouth, I saw the dog cross the road." 22

One further exemplary passage will close this cursory examination of Clifford's Legal Tender opinion:

Comprehensive, however, as the power of Federal taxation is, being without limitation as to amount, still there are some restrictions as to the manner of its exercise, and some exceptions as to the objects to which it may be applied. Bills for raising revenue must originate in the House of Representatives; duties, imposts, and excises must be uniform throughout the United States; direct taxes must be apportioned according to numbers; regulations of commerce and revenue shall not give any preference to the ports of one State over those of another; nor shall vessels bound to or from one State be obliged to enter, clear, or pay duties in another; nor shall any tax or duty be laid on articles exported from any State. ${ }^{63}$

Lest the truly unique inanity of this entirely accurate enumeration escape the inattentive reader, it should be emphasized that it appeared in a case that had nothing whatever to do with federal taxes.

Clifford's detractors like to argue that in his later years he be-

61 79 U.S. (12 Wall.) at 594-95 (Clifford, J., dissenting).

${ }^{2}$ Cf. W. Strunk \& E. White, The Elements of Style 14 (3d ed. 1979) ("Being in a dilapidated condition, I was able to buy the house very cheap."); H. FowLer, A Dictionary of Modern English USAGE 660 (2d ed. 1965) ("Handing me my whisky, his face broke into an awkward smile . . . ."). There remains a nagging doubt as to the antecedent of the critical term "its passage" in the Clifford quotation. Only the context makes it even reasonably clear that this "it" refers to the "act" mentioned in the preceding clause and not to the otherwise unspecified "it" that Clifford had in the meantime said "will be instructive."

ss 79 U.S. (12 Wall.) at 631 (Clifford, J., dissenting). 
came wordy and unfocused, ${ }^{64}$ but the record does not support this facile denigration. After all, the Legal Tender opinion itself was written at a time when Clifford had a full eleven years more to sit, ${ }^{65}$ and it was no isolated instance; comparable opinions authored during the same relatively early period in Clifford's career are briefly noted ${ }^{68}$ in the margin. ${ }^{67}$ Numerous additional examples might be given, ${ }^{68}$ but I think the point has been made; without at this preliminary stage attempting to assign a numerical value to Justice Clifford's IPP, he seems to me to rank significantly higher on this important scale of insignificance than the almost inaudible Duvall. ${ }^{69}$

a E.g., C. Magrath, Morrison R. Waite: The Triumph of Character 260-61 (1963). Cf. C. Fairman, Mr. Justice Miller and the Supreme Court 108-09 (1939), protesting (too loudly?) that it was not true that Clifford was "no better than a nonentity."

is See supra notes 50,52 and accompanying text.

- The inquiring reader (if one exists) may wish to take a peek at Waring v. Mayor of Mobile, 75 U.S. (8 Wall.) 110 (1869), in which Clifford slogged for several pages through the entire body of statutes governing imports without faintly attempting to relate them to the case and then disposed of the actual issue of state power under the Import-Export clause in a single conclusory paragraph; The State Tonnage Tax Cases, 79 U.S. (12 Wall.) 204 (1871), where he stated no fewer than five times that the question was whether the tax in use was a property tax or a duty on tonnage before reaching the difficult conclusion that it was the latter because assessed according to the tonnage of the ship; and Scholey v. Rew, 90 U.S. (23 Wall.) 331, 347-48 (1875), where in a single sentence Clifford concluded that a succession tax was not "direct" because an income tax that had already been held not to be "cannot be distinguished in principle"-without bothering to tell us why.

"Actually, of course, these examples are not noted "in the margin"; "margin" is in this instance a legal fiction for "footnote," as marginal notes in the literal sense went out about the same time as Justice Todd, see supra notes 31-32 and accompanying text. Figuratively, however, a large percentage of footnotes in the typical legal paper can fairly be described as "marginal" in the sense that they might better have been omitted. But see, e.g., Comment, The General Mining Law and the Doctrine of Pedis Possessio: The Case for Congressional Action, 49 U. CrI. L. REv. 1026, $1038 \mathrm{n} .81$ (1982) (citing this author). Needless to say, this argument is inapplicable to the present article. Cf. Blum, Some Marginal Notes on TMT Trailer Ferry Reorganization: The New Math?, 1968 Sur. CT. Rev. 77. See generally P. SAMURLSON, Economics 433-37 (10th ed. 1976) (discussing marginal utility).

4 Several years previously, while carelessly contriving to make the substantively unobjectionable argument that a federal ship license that had been held to preclude the construction of a bridge over the Ohio River forbade the construction of one over the Schuylkill as well, Gilman v. Philadelphia, 70 U.S. (3 Wall.) 713, 733-34 (1865) (Clifford, J., dissenting), he had displayed promise of considerable inanity by his unique disdain for the use of the definite article: "Injury alleged is . . . Bridge about to be erected is . . . . Statement of complaint is . . . . Allegation of the bill of complaint also is . . ." Clifford managed to be quite inconsistent in his eccentricity, as illustrated by the quoted reference to "Allegation of the bill of complaint" (emphasis added); here he omitted the article once and employed it once in identical contexts within a single phrase.

a The judgment of his contemporaries tends to confirm that they ranked Clifford unusually high on the scale of insignificance: three consecutive Chief Justices (Taney, Chase, and Waite) steadfastly refused to assign him anything of importance to write, and the Reporter, Wallace, wondered despairingly whether there had ever before been "such a man 
I have said enough, I think, to suggest something of the value of IPP to counterbalance PPY as an objective indicator of insignificance. One problem that has no doubt occurred to the reader is how to compare Justices with low PPYs (e.g., Duvall) with those scoring high on the IPP scale (e.g., Clifford). I confess to having no ready answer. I can, however; propose additional OII by which the same Justices can be tested to break possible ties.

The first of these indicators I have called EHH? (Ever Heard of Him?). EHH? should be measured by modern double-blind polling techniques by submitting to the $\operatorname{man}^{70}$ in the street ${ }^{71}$ (EHH? ) and to a cross-section of law professors (EHH?p) a list of individuals and asking them to pick out all those on the list who have ever been members of the Supreme Court. Those who are properly identified by the man in the street can be eliminated from the contest as obviously of some significance; those not known to twenty percent of the law professors are serious contenders indeed.

I should caution those who wish to attempt this test that its accuracy depends upon extreme care in devising the list from which the Justices are to be selected. My first experimental list, for example, a representative portion of which is reproduced in the margin, ${ }^{72}$ had to be abandoned after a short trial, for the prevalence of such names as Dolly Madison, Dred Scott, and George Burns quickly led the man in the street ${ }^{73}$ to the correct conclusion that everybody he did not recognize was a former Supreme Court Justice.

The secret of a good questionnaire is to be sneaky. There must be Justices everyone remembers, like John Marshall; there must be names of people one is likely to think might or should have been

. . . in such a place." " C. FAIRMAN, supra note 64 , at 382 (quoting letter from John Wallace to William Maury (Nov. 9, 1880)) (emphasis omitted). Field, in delivering yet a third dissent in the familiar Legal Tender Cases, prefaced his pronouncement with the statement that "I agree with the Chief Justice in the views expressed in his opinion in these cases"-pointedly omitting to say the same of the views that had meanwhile been expressed by Clifford in what must have been the immediately preceding three hours. 79 U.S. (12 Wall.) at 634 (Field, J., dissenting).

70 The term "man" includes "woman." See 1 U.S.C. \$ 1 (1976). It does not include dogs. I do not like dogs. Cf. note 58 and accompanying text. For a contrary opinion, see B. WoodhousE, No BAD DaYS (1980).

72 "Street" is here used in the colloquial sense only. It is not essential that the interviews actually be conducted in the street. Indeed I should advise against doing so in light of the traffic laws, the unavoidable length of the questionnaire, and the fact that dogs sully the street nearly as often as they sully my lawn.

72 George Washington, George Shiras, Howell Jackson, Joe DiMaggio, John McKinley, Hawley Smoot, Hester Prynne, Pontius Pilate, Big Bill Broonzy.

7s See supra notes 70, 71 and accompanying text. 
Justices, like Learned Hand and Daniel Webster; there must be people whose names are easily confused with those of actual Justices, like Edward Livingston, Caleb Cushing, and John Chipman Gray; there should be a misleading plethora of people named Johnson (Andrew, Michael, Thomas, William, and Pearl). Most important of all, there should be a substantial number of people (real or imaginary) who, like Wayne Terwilliger and Emil Verban, have achieved a substantial measure of anonymity in other pastures. In such carefully controlled surroundings, I submit, Justices like Howell Jackson, John Blair, and Samuel Blatchford may find a true test of their own obscurity.

My two remaining OII are NORBB (Number of References by Byrnes) and BVD (Benightedness of View). James F. Byrnes $(1941-42)^{74}$ had one of the shortest Supreme Court careers of any Justice; anyone whose opinions got cited by Justice Byrnes in such a short time (his own colleagues excluded) cannot have been truly insignificant. Benightedness of View, like Inanities Per Page, is a more elusive quality, but I think one must rank high on this scale Justice Pierce Butler, ${ }^{75}$ who is best known to generations of law students for his totally unexplained dissent from the eminently reasonable conclusion of all his brethren that " $[t]$ hree generations of imbeciles are enough."

In closing this preliminary report I cannot be restrained from making special mention of several other Justices who deserve a high place in the ranks of the insignificant. Prominent among them despite his relatively brief service is Alfred Moore of North Carolina (1799-1804), ${ }^{72}$ whom I dismissed in a study of the pre-Marshall era as one who "belong[ed] essentially to the Marshall period"78 and in articles about the Marshall Court as a holdover from earlier days. ${ }^{79}$ Also worthy of mention are the two Justices Lamar, ${ }^{80}$ each so little known that their meager judicial output is commonly thought to be the work of one man; one of them has also the distinction of having had more first names than any other Jus-

76 G. Gunther, supra note 3, at A-6.

7s Butler was on the Court from 1922 until 1939. See id.

78 Buck v. Bell, 274 U.S. 200, 207-08 (1927) (Butler, J., dissenting).

77 G. GuNTHER, supra note 3, at A-2.

78 Currie, The Constitution in the Supreme Court: 1789-1801, 48 U. CHI. L. REv. 819, 820 (1981).

70 Currie, supra note 28, at 646; Currie, supra note 29, at 970.

so L. Lamar was on the Court from 1888 until 1893, J. Lamar from 1910 until 1916. See G. GUNTHER, supra note 3, at A-4, A-5. 
tice would admit to, all three of them in Latin. ${ }^{81}$ Moody, Lurton, Shiras, Day, and Clarke; Cushing, who was senile, ${ }^{82}$ and Baldwin, who was mad; ${ }^{83}$ these are names to be remembered in song and story, lest they not be remembered at all.

I shall take reluctant leave of my subject at this point, chastened that I have not been able to reach a definitive conclusion as to the relative demerits of such admirable candidates as Duvall, Clifford, and McKinley, yet hopeful that my tentative and incomplete efforts may encourage other scholars to give this fascinating question the attention it truly deserves.

81 Lucius Quintus Cincinnatus. See Paul, Lucius Quintus Cincinnatus Lamar, in 2 The Justices of the United States Supreme Court 1789-1969, at 1431, 1431 (H. Friedman \& F. Israel eds. 1969). The other Lamar was Joseph R. G. GunTuER, supra note 3, at A-5. ${ }_{82}$ See 1 C. WARREN, supra note 4, at 400 . As early as 1804 his Brother Johnson had described Cushing as " 'incompetent." " See D. Morgan, supra note 24, at 182 (quoting letter from William Johnson to Thomas Jefferson (Dec. 10, 1822)). John Dickinson wrote that Cushing " "concurred with the majority of the judges and did not add to their exposition of the law." " G. Hastings \& H. Johnson, supra note 32, at 84 (quoting J. Dickinson).

ss See C. Swisher, supra note 39 , at 50-52 \& n.53 (quoting Taney's fear lest the " "evil" " "temper of Judge Baldwin's opinions . . . grow" " to the point where " "[i]t will . . . be necessary to take some step to guard the tribunal from misconstruction" "). 